\title{
Otel İşletmelerinde İçsel Pazarlama Uygulamalarının İşgörenlerin Hizmet Verme Yatkınlığı ve Olumlu Sosyal Davranışları Üzerine Etkisi: Nevşehir Örneği
}

\author{
The Impact of Internal Marketing Applications on Service Orientation and \\ Prosocial Behaviors of Employees in Hotel Businesses: A Case of Nevşehir
}

Yrd. Doç. Dr. Neşe ÇULLU KAYGISIZ

Aksaray Üniversitesi

Turizm Fakültesi

E-posta: nesecullu@hotmail.com

Orcid Id: 0000-0003-2738-1205
Doç. Dr. Duygu EREN

Nevşehir Hacı Bektaş Veli Üniversitesi

Turizm Fakültesi

E-posta:deren@nevsehir.edu.tr Orcid Id: 0000-0002-9959-9521

Öz

Bu çalışmanın amacı, otel işletmelerinde içsel pazarlama uygulamalarının işgörenlerin hizmet verme yatkınlığı ve olumlu sosyal davranışları üzerindeki etkisini ortaya koymaktır. Bu amaçla içsel pazarlamanın bağımsız değişken olduğunu, hizmet verme yatkınlığı ve olumlu sosyal davranışların ise bağımlı değişken olduğunu içeren bir model önerilmiş ve bu model çoklu regresyon analizi ile test edilmiştir. Araştırmada kullanılan veriler, dört ve beş yıldızlı otel işletmelerinde çalışan işgörenlere uygulanan anket yoluyla toplanmış ve verilerin analizi için merkezi eğilim ölçüleri, korelasyon ve regresyon gibi istatiksel analizler kullanılmıştır. Araştırma sonucunda otel işletmelerinde içsel pazarlama uygulamalarının yaygın olduğu, işgörenlerin olumlu sosyal davranışlar sergilediği ve hizmet verme yatkınlıklarının yüksek olduğu tespit edilmiştir. Ayrıca otel işletmelerindeki içsel pazarlama uygulamalarının işgörenlerin hizmet verme yatkınlığı ve olumlu sosyal davranışları üzerinde belirleyici bir etkisi olduğu ortaya çıkmıştır.

Anahtar Kelimeler: Otel işletmeleri, İçsel pazarlama, Hizmet verme yatkınlığı, Olumlu sosyal davranışlar, Nevşehir.

\begin{abstract}
The purpose of this study is to investigate the impact of internal marketing applications on service orientation and prosocial behaviors. In line with the purpose of the study, a causal model consisting of internal marketing as independent variable and prosocial behavior and service orientation as dependent variable was offered and the model was tested with multiple regression analysis. Data were gathered from hotel employees with the help of a questionnaire. Frequencies, descriptive statistics, correlation and regression analysis were used to analyze the data. As a result of the research internal marketing applications in the hotel businesses and employees' prosocial behavior and service orientation were found to be high. In addition, it was found that internal marketing applications have a decisive impact on the service orientation and prosocial behaviors of hotel employees.
\end{abstract}

Keywords: Hotel business, Internal marketing, Service orientation, Prosocial behaviors, Nevşehir. 


\section{Giriş}

Günümüz rekabet koşulları incelendiğinde, otel işletmelerinin ayakta durmasını sağlayan ve işletmelere rekabet üstünlüğü veren en önemli unsurlardan birinin tüketici memnuniyeti olduğu görülmektedir. Tüketici memnuniyetini sağlayıp rekabet üstünlüğü elde etmek için yüksek kalitede hizmet sunan işgörenlere ihtiyaç duyulmaktadır. Otel işletmelerinde tüketici memnuniyeti başarısı büyük ölçüde işgören hizmet davranışlarına bağlıdır. Tüketici ihtiyaç ve isteklerinin sürekli değiştiği çağımızda, işgörenin hizmete olan yatkınlığı ve bunun sonucu olarak sergilediği olumlu davranış şekilleriyle tüketicinin ihtiyaç ve istekleri karşılanabilmektedir. Bu nedenle başarılı olmak isteyen otel işletmelerinin öncelikle çalışanlarının ihtiyaçlarını, isteklerini ve beklentilerini karşılamayı öngören içsel pazarlama uygulamalarına önem vermeleri gerekmektedir.

Otel işletmelerinde üretilen ürünün soyut olması, üretim ve tüketimin eş zamanlı olması gibi özelliklerinden dolayı hizmetlerin yerine getirilmesinde eş güdüm, işbirliği ve iletişim önemlidir. Özellikle üretim ve tüketimin eş zamanlı olması müşterinin üretim yerinde olmasını ve hizmeti sunan işgören ile yüz yüze iletişimi gerektirmesinden dolayı, hizmetin sunuluş tarzı ve işgörenlerin davranışları müşterilerin hizmet kalitesi algılarında belirleyici bir etkiye sahip olmaktadır. Dolayısıyla, otel işletmelerinin başarısı, temelde müşterilerle temas halinde olan çalışanlara bağlıdır ve çalışanların hizmet davranışlarının niteliği, rakiplerinden farkılaşma açısından önemli bir etkendir. $\mathrm{Bu}$ nedenle turizm işletmelerinin öncelikle çalışanların intiyaçlarını, isteklerini ve beklentileri karşılaması gerekir. Araştırmada çalışanları müşteri olarak gören içsel pazarlama uygulamalarının işgörenlerin hizmet verme yatkınlığı ve olumlu sosyal davranışları üzerine etkisini ortaya koymak amaçlanmaktadır.

Modern pazarlama anlayışının temel parçalarından biri olan içsel pazarlama, işgörenlere müşteri gibi davranmayı öngören bir yönetim felsefedir. Çalışanların daha iyi performans göstermesi açısından iç müşteri olarak görülüp istek ve ihtiyaçlarının karşılandığı bir çalışma ortamının oluşturulması şeklinde ifade edilen içsel pazarlama işletmelerin müşteri memnuniyeti sağlayıp rakiplerine karşı üstünlük gösterebilmeleri için odaklanmaları gereken bir yöntemdir (İşler ve Özdemir, 2010). İşgörenlerin tüketicilere hizmet verme konusundaki istekliliği ve hizmet verme sürecinde bireylerarası ilişki ve iletişim yetkinliği, hizmet verme yatkınlığı olarak ifade edilmektedir. Hizmet verme yatkınlığı çalışanların başkalarına yardımcı olma ve onlarla işbirliği içinde olmak için bilinçli bir şekilde çaba göstererek müşterilere ve diğer çalışanlara yüksek düzeyde kaliteli hizmet sunmaktan duyulan hoşnutluk eğilimidir (Petrillose, 1995; Carraher ve diğ.,.. 1998; Donavan, 1999). Olumlu sosyal davranışlar ise, bireylerin karşılık beklemeden diğer bireylere yaptığı yardım davranışlarıdır. Olumlu sosyal davranışlar başka bir insanın ya da bir grup insanın yararına olabilecek, kişinin baskı altında olmadan ve kendi isteğiyle sergilediği davranışlardır (Carlo ve diğ., 2003: 108). İşgörenlerin sahip olduğu hizmet verme yatkınlığı ve olumlu sosyal davranışlar hizmet sunumu esnasında müşteri memnuniyetini sağlayarak hizmet kalitesini artıracaktır. İçsel pazarlama uygulamalarının işletmeler için önemli olan bu iki kavram üzerinde nasıl bir etkiye sahip olduğu bu çalışma ile belirlenmeye çalışılacaktır. Bu çalışmada öncelikle araştırma konusu ile ilgili yazın özetlenmiş, daha sonra araştırmanın yöntemi, bulgular ve sonuç bölümüne yer verilmiştir.

\section{Literatür Taraması}

İçsel pazarlama kavramı ilk olarak Berry ve diğ. (1976) daha sonra George (1977) Thompson ve diğ. (1978) ve Murray (1979) tarafından kullanılmıştır. İçsel pazarlama 
kavramını doğrudan kullanmasalar da bu fikir Sasser ve Arbeit (1976)'ın yaptıkları çalışmada da mevcuttu. Ancak çalışanları iç müşteri olarak görüp örgüt hedeflerine ulaşmak için çalışan istek ve intiyaçlarının karşılanması gerektiği görüşü ilk olarak Berry (1981) tarafından içsel pazarlama kavramı olarak tanımlanmıştır (Rafiq ve Ahmed, 2000). Son yıllarda işletmeler müşteri memnuniyeti ve çalışan memnuniyeti arasındaki ilişkiyi algılayarak çalışan iletişimine, gelişimine ve katılımına önem veren iş süreci düzenlemişlerdir. İçsel pazarlama müşteri odaklı planların başarılı bir şekilde uygulanmasını ve hizmet verimliliğinin artmasını sağlamaktadır. İçsel pazarlama bir işletmede çalışanların ekonomik ihtiyaçlarından ziyade sosyal ihtiyaçlarının geliştirildiği bir kavramdır (Varey ve Lewis, 1999).

Hizmet verme yatkınlığı, doğuştan gelen kişilik özellikleri ile öğrenme deneyiminin etkileşimi ve birleşimi sonucu oluşan, tüketicilerin gereksinimlerini karşılamaya ve iyi hizmet vermeye istekli ve yetenekli olma, tüketicilerle etkili iletişim kurabilme ve bundan zevk alabilme gibi kişilik özelliklerini, tutum ve davranışları kapsayan bireysel özelliklerin tümüdür (Kuşluvan ve Eren, 2011: 142). Hizmet işletmelerinde müşteriler işletmenin kalitesini aldıkları hizmet kalitesine göre değerlendirmektedirler. Böylelikle müşterilere sunulan hizmet örgütsel performansın temel belirleyicisi haline gelmektedir. Bu nedenle örgütsel başarı için hizmet verme yatkınlığı olan personelin istihdam edilmesi ve elde tutulması oldukça önemlidir (Kilchyk, 2009).

Olumlu sosyal davranışlar (prosocial behaviors), bireyin kişisel çıkarı olmaksızın diğerlerinin yararına olan, yardımlaşma ya da paylaşma gibi davranışlar olarak tanımlamaktadır (Hoffmann, 1982: 281). Hizmetin yapısı gereği bir performans olması ve hizmet kalitesinin ağılıklı olarak işgörenin hizmeti nasıl sunduğuna bağlı olması, olumlu sosyal davranışların hizmet kalitesi düzeyini belirleyen kritik unsurlar olduğunu göstermektedir (Yoon ve Suh, 2003: 98).

İlgili yazın incelendiğinde içsel pazarlama, olumlu sosyal davranışlar ve hizmet verme yatkınlığı kavramlarının tek tek incelendiği birçok çalışmaya rastlanılmış fakat bu üç kavramın birbiriyle olan ilişkisini inceleyen bir çalışmaya rastlanılmamıştır. Ancak araştırmanın bağımsız değişkeni olan içsel pazarlama kavramının çalışanların hizmet davranışlarını etkilediği ile ilgili görüşlerin bulunduğu bazı çalışmalar mevcuttur (Rafiq ve Ahmed, 2000; Arnett ve diğ., 2002; Bell ve diğ., 2004; Bellou ve Andronikidis, 2008).

Konu ile ilgili önemli çalışmalardan biri Varey ve Lewis (1999) tarafından yapılan teorik bir çalışmadır. Araştırmacılar yaptıkları çalışmada bugüne kadar içsel pazarlamayla ilgili yazılan literatürü inceleyerek içsel pazarlama kavramını geniş bir açıyla değerlendirmişlerdir. Buna göre içsel pazarlama, müşteri memnuniyeti ve çalışan memnuniyeti arasındaki ilişkiyi düzenleyen çalışan iletişimine, gelişimine ve katılımına önem veren iş sürecidir. Ayrıca içsel pazarlama bir işletmede çalışanların ekonomik intiyaçlarından ziyade sosyal intiyaçlarını karşılamakta; müşteri odaklı planların başarılı bir şekilde uygulanmasını ve hizmet verimliliğinin artmasını sağlamaktadır.

Rafiq ve Ahmed (2000) içsel pazarlama yaklaşımıyla müşteriyle temas halinde bulunan çalışanların müşteriye hizmet sunarken saygılı davranarak ve müşterilerle empati kurarak daha fazla müşteri memnuniyeti sağlanacağını belirtmektedirler. Buna göre hizmet sunan çalışanların tutum ve davranışlarını değiştirmek için çalışanlara müşteri gibi davranmak temel yoldur (Rafiq ve Ahmed, 2000). Özellikle hizmet sektöründe müşteriyle temasta bulunan çalışanların iç müşteri olarak görülmesi işgörenlerin tutum ve davranış değişikliğine yol açabilecektir (Rafiq ve Ahmed, 2002). 
$\mathrm{Bu}$ şekilde istek ve beklentileri yerine getirilerek daha memnun çalışanlar elde edilebilecek ve bu çalışanlar müşterilere daha hevesli ve istekli hizmet sunabilecektir (Rafiq ve Ahmed, 2000).

Arnett ve diğ. (2002)'ne göre turizm işletmelerinde içsel pazarlama stratejileri, hem pozitif işgören tutumu hem de işletmedeki diğer işgörenler ile işbirliğine bağlı kaliteli hizmete yol açan iş tatmini sağlamaktadır. İçsel pazarlama uygulamaları ile özellikle müşteri ile temasta bulunan çalışanların müşteri olarak görülmesi söz konusu işgörenlerin işle ilgili stresini ve iş belirsizliğini azaltacaktır (Rafiq ve Ahmed, 2002).

Crick (2003) turizm sektöründe içsel pazarlamanın başarılı bir şekilde uygulandığında çalışanların uyumunu, eğitimini ve motivasyonunu arttırdığını ve işletmelerin amaçlarına ulaşmasını sağladığını belirtmektedir. Hwang ve Chi'ye (2005) göre ise içsel pazarlama, hem otel çalışanlarının iş tatminini hem de işletme performansını önemli ölçüde etkilemektedir.

Bell ve diğ. (2004)'ne göre güçlü içsel pazarlama uygulamaları müşteri işletme ilişkilerinin başarısında önemli bir koşuldur. Müşteriyle temas halinde olan çalışanların tutum ve davranışları müşterinin gözünde örgütü şekillendirebilmektedir. Ayrıca örgüt ve çalışan arasındaki güçlü ilişkiler hem çalışanın işe karşı motivasyonunu hem de çalışanların müşterilere daha iyi hizmet sunma isteğini geliştirebilecek (Bell ve Mengüç, 2002; Bell ve diğ., 2004) ve dolayısıyla çalışanların hizmet verme yatkınlığını etkileyebilecektir.

Lings (2004), personel davranışlarının hizmet kalitesi algısı üzerinde etkili olduğu görüşünü savunmaktadır. Hizmet sunumu esnasında personelin tutum ve davranışları müşterilerin hizmet kalitesi algısını etkilemekte ve bu nedenle çalışanların tutum ve davranışlarını olumlu yönde değiştirecek içsel pazarlama programlarının işletmeler tarafından düzenlenmesi gerekmektedir. Ayrıca, çalışanların istek ve ihtiyaçları karşılanırsa müşterilere daha iyi hizmet sunacak ve böylelikle işletmeler rekabet avantajı elde edebilecektir (Lings, 2004). Benzer şekilde Başaran ve diğ. (2011) de daha kaliteli hizmet sunulmasında çalışanların davranışlarının önemli olduğunu, bunun için çalışanların birer iç müşteri olarak düşünülmesi gerektiğini belirtmektedir. Bunun için içsel pazarlama uygulamalarından özellikle gelişim ve ödüllendirme unsurlarına önem verilmelidir. Algılanan hizmet kalitesinin artırılmasında öncelikli olarak dikkat edilmesi gereken unsur ise içsel pazarlama unsurlarından ödüllendirmedir (Başaran ve diğ., 2011). Ödüllendirilen çalışanlar karşılıklılık veya eşit çaba gösterme davranışı geliştirebilecek ve bunun karşılığını vermek için daha çok çaba harcayacaktır. Bell ve Mengüç (2002) çalışanlara destekleyici bir çalışma ortamı sunulmasının çalışanların özellikle rol tanımlı olumlu sosyal davranışları ile ilgili karşılıklııık yaratacağını belirtmektedir.

Bellou ve Andronikidis'e (2008) göre iç hizmet kalitesi çalışanların performansını artırmakta ve çalışanların arasındaki işbirliğini arttırarak, işbirliği içinde çalışmalarını sağlamaktadır. Özellikle müşteriyle temasta bulunan çalışanların arasındaki işbirliğinin artması ise hizmet kalitesini artıracaktır (Bell ve Mengüç, 2002).

Hizmet pazarlamasında kullanılan pazarlama karması elemanları çalışanlarda müşteri odaklı davranışlar geliştirmede ve onları motive etmede etkili bir şekilde kullanılabilir (Rafiq ve Ahmed, 1993). Bu şekilde çalışanların özellikle öğrenilebilir kültür tutum ve davranışlar çerçevesinde hizmet verme yatkınlığı ve olumlu sosyal davranışları arttırılabilir. Ayrıca, hizmet kültürünün oluşturulması, insan kaynakları yönetiminde pazarlama yaklaşımının kullanılması, pazarlama bilgisinin çalışanlara 
yayılması, ödül ve farkındalık sisteminin kullanılması şeklinde uygulanan bir içsel pazarlama süreci de çalışanların hizmet verme yatkınlıkları ve olumlu sosyal davranışları üzerinde etkili olabilecektir.

\section{Araştırma Yöntemi}

\subsection{Araştırma Modeli}

Şekil 1'de gösterilen araştırma modeline göre içsel pazarlamanın işgörenlerin hizmet verme yatkınlığını ve olumlu sosyal davranışlarını etkilediği varsayılmaktadır. Sebep sonuç ilişkisini ortaya koyan modelde, araştırmanın bağımsız değişkeni içsel pazarlamadır (vizyon, gelişim, ödül). Araştırmanın bağımlı değişkenleri ise hizmet verme yatkınlığı (müşteriye özel ve önemli olduğunu hissettirme ihtiyacı, müşterinin gereksinim ve isteklerini okuma intiyacı, hizmetleri başarılı bir şekilde sunma arzusu ve kişisel ilişki kurma intiyacı) ve olumlu sosyal davranışlardır (rol tanımlı olumlu sosyal davranışlar, rol ötesi olumlu sosyal davranışlar ve işbirliği).

\section{Şekil 1: Otel İşletmelerinde İçsel Pazarlama Uygulamalarının Hizmet Verme Yatkınlığı ve Olumlu Sosyal Davranışlar Üzerine Etkisi (Yazarlar tarafından geliştirilmiştir).}

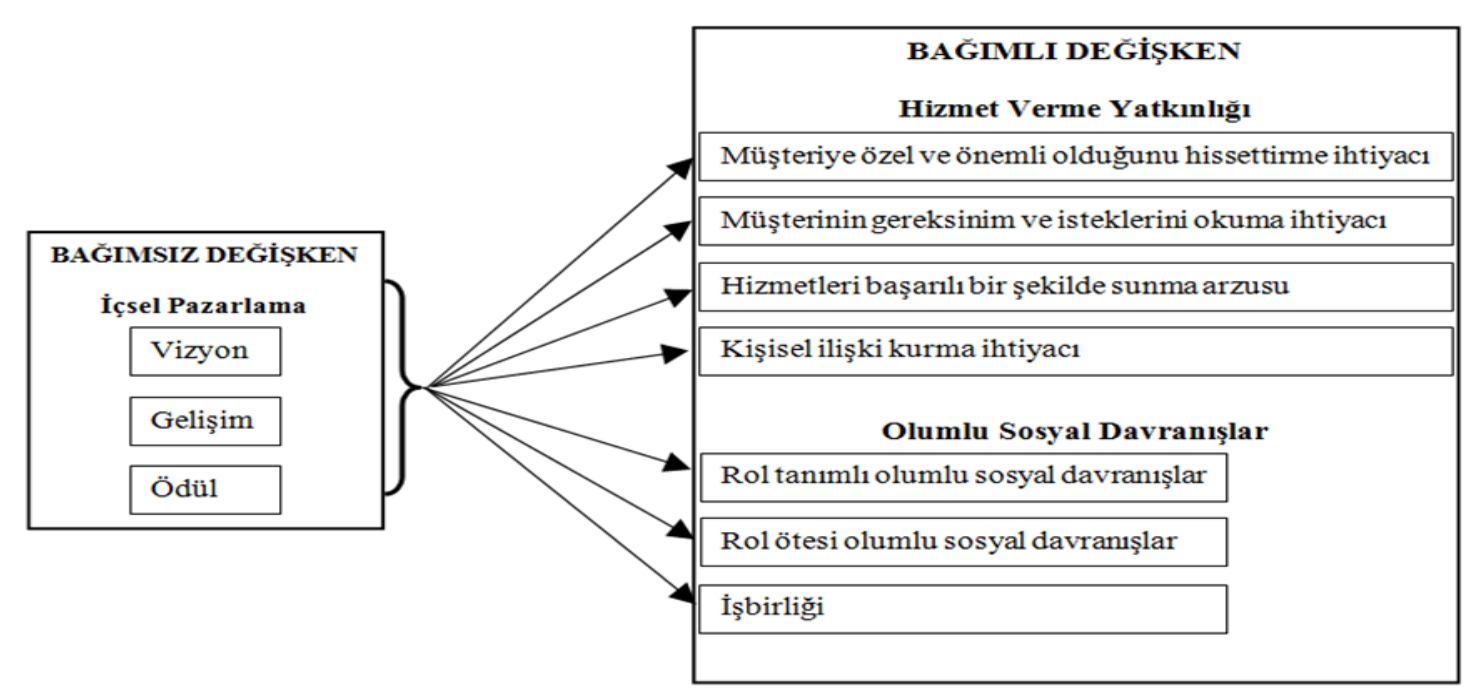

Araştırma modelinde görüldüğü üzere aşağıdaki hipotezler test edilecektir.

$\mathrm{H} 1$ : İçsel pazarlamanın hizmet verme yatkınlığı üzerine pozitif etkisi vardır.

$\mathrm{H} 1_{\mathrm{a}}$ : Vizyonun müşteriye özel ve önemli olduğunu hissettirme ihtiyacı üzerine pozitif etkisi vardır.

$\mathrm{H} 1_{b}$ :Vizyonun müşterinin gereksinim ve isteklerini okuma ihtiyacı üzerine pozitif etkisi vardır.

$\mathrm{H} 1_{\mathrm{c}}$ : Vizyonun hizmetleri başarılı bir şekilde sunma arzusu üzerine pozitif etkisi vardır.

$\mathrm{H} 1_{\mathrm{d}}$ : Vizyonun kişisel ilişki kurma ihtiyacı üzerine pozitif etkisi vardır.

$\mathrm{H} 1_{\mathrm{e}}$ : Gelişimin müşteriye özel ve önemli olduğunu hissettirme ihtiyacı üzerine pozitif etkisi vardır.

$\mathrm{H} 1_{\mathrm{f}}$ : Gelişimin müşterinin gereksinim ve isteklerini okuma intiyacı üzerine pozitif etkisi vardır.

$\mathrm{H} 1_{\mathrm{g}}$ : Gelişimin hizmetleri başarılı bir şekilde sunma arzusu üzerine pozitif etkisi vardır. 
$\mathrm{H} 1_{\mathrm{h}}$ : Gelişimin kişisel ilişki kurma ihtiyacı üzerine pozitif etkisi vardır.

$H 1_{1}$ : Ödülün müşteriye özel ve önemli olduğunu hissettirme ihtiyacı üzerine pozitif etkisi vardır.

$H 1_{i}$ : Ödülün müşterinin gereksinim ve isteklerini okuma ihtiyacı üzerine pozitif etkisi vardır.

$H 1_{j}$ : Ödülün hizmetleri başarılı bir şekilde sunma arzusu üzerine pozitif etkisi vardır.

$\mathrm{H} 11_{\mathrm{k}}$ : Ödülün kişisel ilişki kurma ihtiyacı üzerine pozitif etkisi vardır.

$\mathrm{H} 2$ : İçsel pazarlamanın olumlu sosyal davranışlar üzerine pozitif etkisi vardır.

$\mathrm{H} 2_{\mathrm{a}}$ : Vizyonun rol tanımlı olumlu sosyal davranışlar üzerine pozitif etkisi vardır.

$\mathrm{H} 2_{\mathrm{b}}$ :Vizyonun rol ötesi olumlu sosyal davranışlar üzerine pozitif etkisi vardır.

$\mathrm{H} 2_{\mathrm{c}}$ : Vizyonun işbirliği üzerine pozitif etkisi vardır.

$\mathrm{H} 2_{\mathrm{d}}$ : Gelişimin rol tanımlı olumlu sosyal davranışlar üzerine pozitif etkisi vardır.

$\mathrm{H} 2_{\mathrm{e}}$ : Gelişimin rol ötesi olumlu sosyal davranışlar üzerine pozitif etkisi vardır.

$\mathrm{H}_{\mathrm{f}}$ : Gelişimin işbirliği üzerine pozitif etkisi vardır.

$\mathrm{H}_{2}$ : Ödülün rol tanımlı olumlu sosyal davranışlar üzerine pozitif etkisi vardır.

$\mathrm{H} 2 \mathrm{~h}$ : Ödülün rol ötesi olumlu sosyal davranışlar üzerine pozitif etkisi vardır.

H2: Ödülün işbirliği üzerine pozitif etkisi vardır.

\subsection{Araştırmanın Değişkenleri ve Ölçümü}

Araştırmada otel işletmelerinde içsel pazarlama uygulamalarının işgörenlerin hizmet verme yatkınlığı ve olumlu sosyal davranışları üzerine etkisi ölçülmüş ve söz konusu üç değişken arasındaki ilişki incelenmiştir. Bu nedenle araştırmanın bağımsız değişkeni içsel pazarlamadır. Araştırmanın bağımsız değişkenini oluşturan içsel pazarlamayı ölçmek için Foreman ve Money (1995) tarafından geliştirilen "İçsel Pazarlama Ölçeği" kullanılmıştır. İçsel pazarlama ölçeği vizyon, gelişim ve ödül olmak üzere 3 boyuttan ve 15 maddeden oluşmaktadır. Ölçekte yer alan ifadeler 5 'li Likert tipi ölçekle ölçülmüştür (1= Kesinlikle Katılmıyorum, 2=Katılmıyorum, 3=Ne Katılıyorum Ne Katılmıyorum, 4=Katılıyorum, 5=Kesinlikle Katılıyorum).

Araştırmanın bağımlı değişkeni olan hizmet verme yatkınlığını ölçmek için Donavan, Brown ve Mowen (2004) tarafından geliştirilen hizmet verme yatkınlığı ölçeği kullanılmıştır. Ölçek 4 boyuttan ve 13 maddeden oluşmaktadır. Bu boyutlar; müşteriye özel ve önemli olduğunu hissettirme ihtiyacı, müşterinin gereksinim ve isteklerini okuma/anlama ihtiyacı, hizmetleri başarılı bir şekilde sunma arzusu ve kişisel ilişki kurma intiyacı boyutudur. Ölçekte yer alan ifadeler $5^{\prime}$ li Likert tipi ölçekle ölçülmüştür (1= Kesinlikle Katılmıyorum, 2=Katılmıyorum, 3=Ne Katılıyorum $\mathrm{Ne}$ Katılmıyorum, 4=Katılıyorum, 5=Kesinlikle Katılıyorum).

Araştırmanın diğer bağımlı değişkeni olan olumlu sosyal davranışları ölçmek için ise Bettencourt ve Brown (1997) tarafından geliştirilen; rol tanımlı olumlu sosyal davranışlar, rol ötesi olumlu sosyal davranışlar ve işbirliği olmak üzere 3 boyuttan ve 15 maddeden oluşan Olumlu Sosyal Davranışlar (OSD) ölçeği kullanılmıştır. Ölçekte yer alan ifadeler 5 'li Likert tipi ölçekle ölçülmüştür (1= Kesinlikle Katılmıyorum, 2=Katılmıyorum, 3=Ne Katılıyorum $\mathrm{Ne}$ Katılmıyorum, 4=Katılıyorum, 5=Kesinlikle Katılıyorum).

\subsection{Evren ve Örneklem}

Araştırmanın evrenini Nevşehir ilinde faaliyet gösteren 4 ve 5 yıldızı ıtel işletmelerinde çalışan işgörenler oluşturmaktadır. Nevşehir'de bulunan 4 ve 5 yıldızlı otel işletmelerinin araştırma evreni olarak belirlenmesinin nedeni bu bölgenin turizm açısından önemli bir destinasyon olması ve bu tesislerin yönetim ve örgüt yapılarının 
araştırmanın amacına uygun olmasıdır. Nevşehir İ ve Kültür Turizm Müdürlüğü’nün 2016 yılı verilerine göre Nevşehir'de 8 adet beş yıldızlı, 20 adet 4 yıldızlı otel işletmesi bulunmaktadır. Araştırmanın zaman ve maliyet kısıtları, araştırma evreni üzerinde tamsayım yapmak mümkün olmadığı için örneklemeye gidilmiştir.

Araştırmada örnekleme yöntemi olarak, tesadüfî olmayan örnekleme yöntemlerinden yargısal örnekleme yöntemi tercih edilmiştir. Yargısal örneklemede örneği oluşturan elemanlar araştırmacının araştırma problemlerine cevap bulacağına inandığı kişilerden oluşur (Altunışık vd., 2007). Bu yöntemde, seçilen örneğin araştırmanın amacına uygun olduğu ve araştırmacının aradığı bilgiyi sağlayacağı varsayılır (Churchil 1996). Ancak, yargısal örnekleme yöntemi ile seçilen örneğin evreni ne derece temsil ettiği bilinmediğinden, evren hakkında genelleme yapılamamaktadır (Malhotra, 1996).

Veri toplama aracı olarak oluşturulan anket 10.02.2016-20.06.2016 tarihleri arasında anketi uygulamayı kabul eden 4 ve 5 yıldızlı otel işletmelerine bırakılmış ve bir süre sonra geri toplanmıştır. Kabul edilebilir örneklem büyüklüğüne ulaşabilmek için otel işletmelerine toplam 500 adet soru formu bırakılmıştır. Soru formuna tam olarak cevap verilmemesi ve birden fazla seçeneğin işaretlenmesi gibi nedenlerle geçerliliği olmayan soru formları ayıklandıktan sonra 319 adet anket araştırmada kullanılmıştır. Dağıtılan anketlerden \% 63,8 oranında geri dönüş elde edilmiştir.

\subsection{Veri Toplama Yöntemi ve Verilerin Analizi}

Veriler araştırmanın bağımlı ve bağımsız değişkenleriyle ilgili ölçek maddelerini ve araştırmaya katılan işgörenlerin özellikleriyle ilgili soruları içeren anket yoluyla toplanmıştır. Toplanan veriler bilgisayar ortamında analiz edilmiştir. Analizlerde işgörenlerin demografik özelliklerini test etmek için frekans, yüzde dağılımları ve aritmetik ortalama gibi merkezi eğilim ölçüleri ile bağımsız değişken (içsel pazarlama) ile bağımlı değişkenler (hizmet verme yatkınlığı, olumlu sosyal davranışlar) arasındaki ilişkiyi test etmek için korelasyon analizi ve bağımsız değişkenin bağımlı değişken üzerindeki etkisini test etmek için ise regresyon analizi gibi istatistiksel analiz yöntemlerinden faydalanılmıştır.

\section{Bulgular}

\subsection{Araştırmada Kullanılan Ölçeklerin Güvenilirlikleri ve Geçerlilikleri}

Tablo 1'de araştırmada kullanılan ölçeklerin önerme sayıları ve güvenilirlik kat sayıları (Cronbach Alpha) verilmiştir. Robinson ve Shaver (1973) araştırmalarda kullanılan ölçeklerin güvenilirlik katsayısının (Cronbach's alpha) en az 0,70 olması gerektiğini belirtmektedir (Hair ve diğ., 1998:118). Tablo 1'de de görüldüğü üzere, araştırmada kullanılan ölçeklerin güvenilirlik katsayısının yüksek ve tatmin edici düzeyde $(\alpha>0,70)$ olduğu gözlenmiştir. Araştırmada kullanılan ölçeklerin geçerliliğinin test edilmesi için öncelikle uzaksak (divergent validity) daha sonra da yakınsak geçerliliğine (convergent validity) bakılmıştır. Uzaksak geçerlilik, bir yapıya ilişkin ölçekle farklı yapıları ölçen ölçekler arasında düşük korelasyonun olması anlamına gelmektedir (Altunışık ve diğ., 2007: 113). Uzaksak geçerlilik için madde analizi yapılır ve ölçekte yer alan her bir maddenin kendi boyutu (ilgili maddenin kendi boyut toplamından çıkartılarak) ve diğer boyutlar ile korelasyonları incelenir. Yapılan madde analizi sonucunda içsel pazarlama, hizmet verme yatkınlığı ve olumlu sosyal davranışlar ölçeğinde yer alan her bir maddenin kendi boyutu ile gösterdiği korelasyonun diğer boyutlar ile gösterdiği korelasyona göre daha yüksek olduğu ortaya çıkmıştır. Araştırmada kullanılan 
ölçeklerin yakınsak geçerlilikleri (convergent validity) için ise bütün alt ölçeklerin birbiriyle olan korelasyonuna bakılmıştır. Judd ve diğ. (1991: 165) alt ölçeklerin birbiriyle olan korelasyonunun düşük fakat aynı zamanda olumlu olması gerektiğini belirtmektedir (Aktaran Eren, 2007). İçsel pazarlama, hizmet verme yatkınlığı ve olumlu sosyal davranışlar ölçeğinin yakınsak geçerliliği analiz sonuçlarına göre her bir alt ölçeğin diğerleriyle olan korelasyonu düşük, fakat $p<0,01$ ve $p<0,05$ düzeyinde olumlu ve anlamlıdır. Güvenilirlik ve geçerlilik analizi sonuçları, araştırmada kullanılan bütün ölçeklerin geçerli ve güvenilir ölçekler olduğunu göstermektedir.

Tablo 1: Araştırmada Kullanılan Ölçekler ve Güvenilirlik Katsayıları

\begin{tabular}{|c|c|c|}
\hline Ölçekler & Madde Sayısı & Cronbach Alpha (a) \\
\hline İçsel Pazarlama & $\mathbf{1 5}$ & $\mathbf{0 , 9 4}$ \\
\hline Vizyon & 3 & 0,81 \\
\hline Gelişim & 8 & 0,90 \\
\hline Ödül & 4 & 0,88 \\
\hline Olumlu Sosyal Davranışlar & $\mathbf{1 5}$ & $\mathbf{0 , 9 4}$ \\
\hline Rol Ötesi & 5 & 0,96 \\
\hline Rol Tanımlı & 5 & 0,91 \\
\hline Işbirliği & 5 & 0,93 \\
\hline $\begin{array}{c}\text { Müşteriye Özel ve Önemli Olduğunu } \\
\text { Hissettirme İhtiyacı }\end{array}$ & $\mathbf{1 3}$ & $\mathbf{0 , 9 1}$ \\
\hline $\begin{array}{c}\text { Müşterinin Gereksinim ve İsteklerini } \\
\text { Okuma/Anlama İhtiyacı }\end{array}$ & 4 & 0,87 \\
\hline $\begin{array}{c}\text { Hizmetleri Başarııı Bir Şekilde Sunma } \\
\text { Arzusu }\end{array}$ & 3 & 0,79 \\
\hline Kişisel Ilişki Kurma İhtiyacı & 2 & 0,89 \\
\hline
\end{tabular}

\subsection{Araştırmaya Katılan İşgörenlerin Özellikleri}

Tablo 2'deki araştırmaya katılan işgörenlerin özellikleri ile ilgili araştırma sonuçları incelendiğinde, katılımcıların çoğunluğunun kadın olduğu görülmektedir (\%58). Araştırmaya katılan işgörenlerin medeni durumu incelendiğinde büyük kısmının evli olduğu anlaşılmaktadır (\%62,1). Araştırmaya katılan işgörenlerin yaşlarına bakıldığında genç nüfusun çoğunlukta olduğu görülmektedir (\%62). Anketi cevaplayan işgörenlerin büyük kısmının eğitim seviyesinin lisansın altında olduğu tespit edilmiştir $(\% 75,5)$. Araştırmaya katılan işgörenlerin çalıştıkları departmanlar incelendiğinde \% 34,7'nin kat hizmetlerinde, \%21'in mutfakta, \%21,3'nün önbüroda ve \%22,9'un ise yiyecek içecek bölümünde çalıştıkları anlaşılmaktadır. Araştırmaya katılan işgörenlerin işletmede çalışma sürelerine bakıldığında ise \%85'inin 1-5 yıl arası işletmede çalıştığı görülmektedir. Tüm bu verilere dayanarak anketi cevaplayan işgörenlerin genellikle kadın, evli, 18-29 yaş aralığında, lise mezunu, kat hizmetleri departmanında ve işletmede 1-5 yıl arasında çalıştıkları söylenebilir.

Tablo 2: Araştırmaya Katılan Otel Çalışanlarının Demografik Özellikleri

\begin{tabular}{|c|c|c|c|}
\hline & $\mathbf{N}$ & Frekans & Yüzde (\%) \\
\hline Cinsiyet & 319 & & 42 \\
\hline Erkek & & 134 & 58 \\
\hline Kadın & & 185 & \\
\hline Medeni Hal & 319 & & 37,9 \\
\hline Bekar & & 121 & 62,1 \\
\hline Evli & & 198 & \\
\hline
\end{tabular}


Tablo 2'nin devamı

\begin{tabular}{|} 
Tablo 2'nin devamı \\
\begin{tabular}{|c|c|c|c|}
\hline Yaş & 319 & & \\
\hline $18-23$ & & 38 & 11,9 \\
\hline $24-29$ & & 118 & 37 \\
\hline $30-35$ & & 80 & 25,1 \\
\hline $36-41$ & & 55 & 17,2 \\
\hline 42 ve üstü & & 28 & 8,8 \\
\hline Eğitim Düzeyi & 319 & & 33,2 \\
\hline İlköğretim & & 106 & 42,3 \\
\hline Ortaöğretim & & 135 & 19,7 \\
\hline Lisans & & 63 & 4,7 \\
\hline Lisansüstü & & 15 & 34,7 \\
\hline Departman & 319 & & 21 \\
\hline Kat Hizmetleri & & 111 & 21,3 \\
\hline Mutfak & & 67 & 22,9 \\
\hline Önbüro & & 68 & 85 \\
\hline Yiyecek-içecek & & 73 & 12,9 \\
\hline Çalışma Süresi & 319 & & 1,9 \\
\hline $1-5$ & & 271 & 0,3 \\
\hline $6-10$ & 41 & \\
\hline $11-15$ & & 6 & \\
\hline 16 ve üstü & & 1 & \\
\hline
\end{tabular}
\end{tabular}

\section{3. İçsel Pazarlama, Hizmet Verme Yatkınlığı ve Olumlu Sosyal Davranışlara İlişkin Bulguların Değerlendirilmesi}

Tablo 3'de içsel pazarlama, hizmet verme yatkınlığı ve olumlu sosyal davranışlar ölçeklerinin alt ölçeklerine ait bazı tanımlayıcı istatistikler verilmiştir.

Tablo 3: Araştırmada Kullanılan Ölçekler ve Alt Ölçeklerle İıgili Bazı Tanımlayıcı İstatistikler

\begin{tabular}{|c|c|c|}
\hline Ölçekler & Genel Ortalama & Standart Sapma \\
\hline İçsel Pazarlama ${ }^{\top}$ & 3,98 & 0,93 \\
\hline Vizyon & 4,01 & 1,16 \\
\hline Gelişim & 3,99 & 0,94 \\
\hline Ödül & 3,92 & 1,16 \\
\hline Hizmet Verme Yatkınlığı ${ }^{2}$ & 3,94 & 0,93 \\
\hline $\begin{array}{c}\text { Müşteriye Özel ve Önemli Olduğunu Hissettirme } \\
\text { İhtiyacl }\end{array}$ & 3,82 & 1,32 \\
\hline Müşterinin Gereksinim ve İsteklerini Anlama İhtiyacı & 3,92 & 1,15 \\
\hline Hizmetleri Başarııı Bir Şekilde Sunma Arzusu & 4,05 & 1,04 \\
\hline Kişisel İlişki Kurma İhtiyacı & 4,07 & 1,10 \\
\hline Olumlu Sosyal Davranışlar ${ }^{3}$ & 3,92 & 0,96 \\
\hline Rol Ötesi & 3,91 & 1,29 \\
\hline Rol Tanımlı & 3,87 & 1,02 \\
\hline İşbirliği & 3,92 & 1,11 \\
\hline
\end{tabular}

Tablo 3 incelendiğinde, işgörenlerin genel olarak içsel pazarlama uygulamalarını yüksek olarak değerlendirdikleri anlaşılmaktadır $(3,98)$. İçsel pazarlamayı oluşturan boyutlardan en yüksek ortalama vizyon boyutunundur $(4,01)$. Bu durumda işletmenin çalışanlarına inanabilecekleri bir vizyon sunduğu ve vizyonunu çalışanlarına uygun bir şekilde ilettiği söylenebilir. İşgörenlerin hizmet verme yatkınlığına ilişkin değerlendirmeleri incelendiğinde, hizmet verme yatkınlıklarının yüksek olduğu 
görülmektedir $(3,94)$. Ancak, hizmet verme yatkınlığı boyutlarından kişisel ilişki kurma intiyacı boyutunun ortalaması diğer boyutlara göre daha yüksektir $(4,07)$. Bu durumda, işgörenlerin müşterilere daha iyi hizmet sunmak için kişisel ilişki kurarak onları yakından tanımaya istekli oldukları söylenebilir. Olumlu sosyal davranışlarla ilgili değerlendirmelere bakıldığında, katılımcıların genel olarak olumlu sosyal davranışlarını yüksek olarak değerlendirdikleri görülmektedir $(3,92)$. Olumlu sosyal davranışları oluşturan boyutlardan işbirliği boyutunun ortalamasının diğer boyutlara göre daha yüksek çıkması dikkat çekicidir $(3,92)$. Bu durum sonucunda işgörenlerin iş yükü çok olan diğer çalışanlara yardım ettiği ve bu yardım için isteyerek zaman ayırdıkları söylenebilir.

\section{4. İçsel Pazarlama, Hizmet Verme Yatkınlığı ve Olumlu Sosyal Davranışlar İlişkisi}

Tablo 4'te içsel pazarlamayı oluşturan boyutlar ile hizmet verme yatkınlığını oluşturan boyutlar arasındaki korelasyon katsayıları verilmiştir. Tablo incelendiğinde içsel pazarlamanın bütün boyutları ile hizmet verme yatkınlığının bütün boyutları arasındaki korelasyon katsayıları $p=0,01$ düzeyinde pozitif ve anlamlıdır. Vizyon ile en yüksek korelasyon hizmet verme yatkınlığının hizmetleri başarılı bir şekilde sunma arzusu boyutu $(0,476)$ arasındadır. Tablo incelendiğinde gelişim boyutu ile hizmetleri başarılı bir şekilde sunma arzusu boyutu $(0,550)$ arasında yüksek korelasyon olduğu görülmektedir. Ödül ile en yüksek korelasyon ise yine hizmetleri başarılı bir şekilde sunma arzusu boyutu $(0,460)$ arasındadır. Genel içsel pazarlama ile genel hizmet verme yatkınlığı arasındaki korelasyon ise 0,580 'dir. Genel olarak tablo incelendiğinde içsel pazarlama ile hizmet verme yatkınlığı arasında pozitif ve anlamlı düzeyde bir ilişki olduğu söylenebilir.

\section{Tablo 4: İçsel Pazarlama ve Hizmet Verme Yatkınlığı Arasındaki Korelasyon Katsayıları (Pearson)}

\begin{tabular}{|c|c|c|c|c|c|}
\hline & $\begin{array}{l}\text { Müşteriye Özel } \\
\text { Olduğunu } \\
\text { Hissettirme İhtiyacı }\end{array}$ & $\begin{array}{c}\text { Müşterinin } \\
\text { İsteklerini } \\
\text { Anlama } \\
\text { İhtiyacı }\end{array}$ & $\begin{array}{c}\text { Hizmetleri } \\
\text { Başarılı Bir } \\
\text { Şekilde Sunma } \\
\text { Arzusu }\end{array}$ & $\begin{array}{l}\text { Kişisel İlişki } \\
\text { Kurma } \\
\text { İhtiyacı }\end{array}$ & $\begin{array}{l}\text { Hizmet } \\
\text { Verme } \\
\text { Yatkınlığı }\end{array}$ \\
\hline $\begin{array}{l}\text { Içsel } \\
\text { Pazarla } \\
\text { ma }\end{array}$ & $0,411^{* *}$ & $0,483^{\star *}$ & $0,545^{* *}$ & $0,468^{* *}$ & $0,580^{* *}$ \\
\hline Vizyon & $0,346^{* *}$ & $0,384^{* *}$ & $0,476^{* *}$ & $0,413^{* *}$ & $0,488^{* *}$ \\
\hline Gelişim & $0,400^{\star \star}$ & $0,480^{\star *}$ & $0,550^{\star \star}$ & $0,461^{\star *}$ & $0,574^{\star \star}$ \\
\hline Ödül & $0,386^{* *}$ & $0,454^{\star *}$ & $0,460^{* \star}$ & $0,413^{\star *}$ & $0,526^{\star *}$ \\
\hline
\end{tabular}

Tablo 5'te içsel pazarlamayı oluşturan boyutlar ile olumlu sosyal davranışları oluşturan boyutlar arasındaki korelasyon katsayıları verilmiştir. Tablo incelendiğinde içsel pazarlamanın bütün boyutları ile olumlu sosyal davranışların bütün boyutları arasındaki korelasyon katsayıları $p=0,01$ düzeyinde pozitif ve anlamlıdır. Vizyon ile en yüksek korelasyon olumlu sosyal davranışların rol tanımlı olumlu sosyal davranışlar boyutu $(0,460)$ arasındadır. Tablo incelendiğinde gelişim ile rol tanımlı olumlu sosyal davranışlar boyutu $(0,539)$ arasında yüksek korelasyon olduğu görülmektedir. Ödül ile en yüksek korelasyon ise yine rol tanımlı olumlu sosyal davranışlar boyutu $(0,515)$ arasındadır. Genel içsel pazarlama ile genel olumlu sosyal davranışlar arasındaki korelasyon ise $0,613^{\prime}$ tür. Genel olarak tablo incelendiğinde içsel pazarlama ile olumlu sosyal davranışlar arasında pozitif ve anlamlı düzeyde bir ilişki olduğu söylenebilir. 
Tablo 5: İçsel Pazarlama ve Olumlu Sosyal Davranışlar Arasındaki Korelasyon Katsayıları (Pearson)

\begin{tabular}{|c|c|c|c|c|}
\hline & Rol Ötesi & Rol Tanımlı & İşbirliği & OSD \\
\hline İçsel Pazarlama & $0,517^{\star \star}$ & $0,551^{\star \star}$ & $0,506^{\star \star}$ & $0,613^{* *}$ \\
\hline Vizyon & $0,447^{\star *}$ & $0,460^{\star \star}$ & $0,404^{\star \star}$ & $0,512^{\star *}$ \\
\hline Gelişim & $0,499^{* *}$ & $0,539^{\star *}$ & $0,494^{* *}$ & $0,596^{* *}$ \\
\hline Ödül & $0,481^{* \star}$ & $0,515^{\star \star}$ & $0,491^{\star \star}$ & $0,579^{\star *}$ \\
\hline
\end{tabular}

Otel işletmelerindeki içsel pazarlama ile işgörenlerin hizmet verme yatkınlığı ve olumlu sosyal davranışları arasındaki sebep-sonuç ilişkisini ortaya koymak amacıyla Şekil 1'de yer alan araştırma modeli test edilmiştir. Bağımsız değişkenlerin hizmet verme yatkınlığı ve olumlu sosyal davranışlar üzerindeki etkisini test etmek için çoklu regresyon analizi yapılmıştır. Araştırma modeli test edilmeden önce bağımsız değişkenler arasında çoklu bağlantı (multicollinearity) problemi olup olmadığı incelenmiştir. Çoklu bağlantı, üç veya daha fazla bağımsız değişken arasındaki ilişkiyi tanımlamaktadır. Çoklu bağlantı, herhangi bir bağımsız değişkenin açıklayıcı gücünü azaltır (Hair ve diğ., 1998: 156). Modelde ikiden fazla bağımsız değişken olmasından dolayı öncelikle bağımsız değişkenler arasında çoklu bağlantı olup olmadığı incelenmiştir. Bağımsız değişkenler arasında çoklu bağlantı olup olmadığını belirlemek için varyans artış faktörü (variance inflation factor-VIF) ve tolerans değerleri incelenmiştir. Varyans artış faktörü 10,0'dan büyük ve tolerans değeri de 0,10'dan küçük olursa çoklu bağlantı probleminin olduğu kabul edilir (Hair vd., 1998: 193). Yapılan analiz sonucuna göre, bağımsız değişkenlerin varyans artış faktörleri 10,0'dan küçük ve tolerans değerleri ise 0,10 'dan büyüktür. Dolayısıyla bağımsız değişkenler arasında çoklu bağlantı sorununun olmadığı sonucuna varılmıştır.

Tablo 6: Hizmet Verme Yatkınlığı ve Olumlu Sosyal Davranışları Etkileyen İçsel Pazarlama Boyutları

\begin{tabular}{|c|c|c|c|c|}
\hline $\begin{array}{c}\text { İçsel Pazarlama } \\
\text { Boyutları }\end{array}$ & Hizmet Verme Yatkınlığı & Uyarlanmış $R^{2}$ & $\beta$ & $\mathbf{P}$ \\
\hline $\begin{array}{c}\text { Gelişim } \\
\text { Ödül }\end{array}$ & $\begin{array}{c}\text { Müşteriye Özel ve Önemli Olduğunu } \\
\text { Hissettirme İhtiyacı }\end{array}$ & 0,17 & $\begin{array}{l}0,23 \\
0,18\end{array}$ & $\frac{0,05}{0,03}$ \\
\hline $\begin{array}{c}\text { Gelişim } \\
\text { Ödül }\end{array}$ & $\begin{array}{c}\text { Müşterinin Gereksinim ve İsteklerini } \\
\text { Okuma İhtiyacı }\end{array}$ & 0,24 & $\frac{0,40}{0,19}$ & $\begin{array}{l}0,00 \\
0,01\end{array}$ \\
\hline Gelişim & $\begin{array}{c}\text { Hizmetleri Başarılı Bir Şekilde } \\
\text { Sunma Arzusu }\end{array}$ & 0,30 & 0,48 & 0,00 \\
\hline Gelişim & Kişisel İlişki Kurma İhtiyacı & 0,21 & 0,29 & 0,01 \\
\hline $\begin{array}{c}\text { İçsel Pazarlama } \\
\text { Boyutları }\end{array}$ & Olumlu Sosyal Davranışlar & Uyarlanmış $\mathbf{R}^{2}$ & $\beta$ & $\mathbf{P}$ \\
\hline $\begin{array}{c}\text { Gelişim } \\
\text { Ödül }\end{array}$ & $\begin{array}{c}\text { Rol Tanımlı Olumlu Sosyal } \\
\text { Davranışlar }\end{array}$ & 0,30 & $\begin{array}{l}0,34 \\
0,23 \\
\end{array}$ & $\frac{0,00}{0,00}$ \\
\hline $\begin{array}{l}\text { Gelişim } \\
\text { Ödül } \\
\end{array}$ & $\begin{array}{c}\text { Rol Ötesi Olumlu Sosyal } \\
\text { Davranışlar }\end{array}$ & 0,26 & $\begin{array}{l}0,24 \\
0,23 \\
\end{array}$ & $\begin{array}{l}0,03 \\
0,00\end{array}$ \\
\hline $\begin{array}{c}\text { Gelişim } \\
\text { Ödül }\end{array}$ & İşbirliği & 0,26 & $\begin{array}{l}0,33 \\
0,26\end{array}$ & $\begin{array}{l}0,00 \\
0,00\end{array}$ \\
\hline
\end{tabular}

Tablo 6'da içsel pazarlamanın hizmet verme yatkınlığı ve olumlu sosyal davranışlar üzerindeki etkisine ilişkin regresyon analizi sonuçları verilmiştir. Tabloda görüldüğü gibi içsel pazarlamanın gelişim ve ödül boyutları hizmet verme yatkınlığını ve olumlu sosyal davranışları etkilemekte ve katkı sağlamaktadır. Başka bir deyişle, otel işletmelerinde çalışan işgörenlerin hizmet verme yatkınlıkları ve olumlu sosyal 
davranışları üzerinde işletmelerin uyguladığı gelişim ve ödül sistemleri etkili ve önemlidir. Bu durumda içsel pazarlamayla ilgili uygulamaların nispeten birbirine bağlı ve birbirini etkileyen uygulamalar olduğu söylenebilir. Bu nedenle hizmet verme yatkınlığı ve olumlu sosyal davranışlar üzerinde etkisi bulunmayan içsel pazarlama boyutunun (vizyon) önemsiz olduğu anlamına gelmemektedir. İçsel pazarlamanın bütün boyutlarının hizmet verme yatkınlığı ve olumlu sosyal davranışlar üzerindeki etkisinin olmamasının nedeni, işgörenlerin hizmet davranışlarının sadece bu tür uygulamalara bağlı olmadığıdır. İşgörenlerin hizmet davranışlarının başarısı işgören seçimiyle de ilgilidir. İşgören seçiminde özellikle işe uygun kişilerin seçilmesi işgörenlerin hizmet davranışlarını etkileyebilir. Bu durum, otel işletmelerindeki içsel pazarlama uygulamalarının işgörenlerin hizmet verme yatkınlığı ve olumlu sosyal davranışlarına yaptığı katkıyı etkileyebilir.

\section{Sonuç ve Öneriler}

$\mathrm{Bu}$ araştırmada otel işletmelerindeki içsel pazarlama uygulamaları tespit edilmiş, otel çalışanlarının hizmet verme yatkınlığı ve olumlu sosyal davranış düzeyleri belirlenmiş, otel işletmelerinde içsel pazarlama uygulamalarının hizmet verme yatkınlığı ve olumlu sosyal davranışlar üzerine etkisi incelenmiştir. Bunun için bir model geliştirilmiş ve model Nevşehir ilinde faaliyet gösteren 4 ve 5 yıldızlı otellerde çalışan işgörenler üzerinde test edilmiştir. Araştırma sonuçlarına göre, işgörenler çalıştıkları otel işletmelerinde içsel pazarlama uygulamalarını yüksek olarak değerlendirmektedirler. Ayrıca işgörenler kendilerini hizmet vermeye yatkın ve olumlu sosyal davranışlar sergileyen işgörenler olarak algılamaktadırlar. Otel işletmelerindeki içsel pazarlama uygulamaları ile işgörenlerin hizmet verme yatkınlığı arasında yapılan analizler sonucunda, içsel pazarlamanın bütün boyutları ile hizmet verme yatkınlığının boyutlarının hepsi arasında pozitif ve istatistiki olarak anlamlı korelasyon bulunmuştur. İçsel pazarlamanın boyutları olan vizyon, gelişim ve ödül ile en yüksek korelasyon hizmetleri başarılı bir şekilde sunma arzusu arasındadır. Otel işletmelerinin içsel pazarlama uygulamalarının işgörenlerin daha iyi hizmet verme isteğini artırdığı söylenebilir. Araştırmada otel işletmelerindeki içsel pazarlama uygulamaları ile işgörenlerin olumlu sosyal davranışları arasında pozitif ve anlamlı ilişkiler tespit edilmiştir. İçsel pazarlamanın boyutları olan vizyon, gelişim ve ödül ile en yüksek korelasyon rol tanımlı olumlu sosyal davranışlar arasındadır. Bu durumda otel işletmelerindeki içsel pazarlama uygulamalarının çalışanların kendilerinden beklenen hizmet davranışlarını sergilemelerine yardımcı olduğu söylenebilir. Araştırma sonuçları incelendiğinde içsel pazarlamanın farklı boyutlarının farklı hizmet verme yatkınlığı boyutlarına katkı sağladığı anlaşıımaktadır. Gelişim ve ödül boyutlarının müşteriye özel ve önemli olduğunu hissettirme ihtiyacı boyutuna ve müşterinin gereksinim ve isteklerini okuma ihtiyacı boyutuna büyük oranda katkı sağladığı saptanmıştır. Gelişim boyutu hizmetleri başarılı bir şekilde sunma arzusu boyutuna ve kişisel ilişki kurma intiyacı boyutuna katkı sağlamaktadır. Bu durumda işgörenlerin müşterilere özel ilgi göstererek müşterilerin ihtiyaçlarını onlar söylemeden anlayabilmesi için işletme tarafından gelişim ve ödül gibi çeşitli uygulamalarla teşvik edilmeleri gerektiği söylenebilir. Çeşitli uygulamalarla ödüllendirilen işgörenlerin iş tatmini artacak ve daha istekli bir şekilde işletmenin amaçlarına ulaşmasına yardımcı faaliyetler içinde bulunacaktır. İşgörenlerin çeşitli eğitim ve geliştirme faaliyetleri ile iş ile ilgili yeterlilikleri artırılarak müşterilere daha başarılı hizmet sunmaları sağlanabilir. Hizmet sektöründe üretim ve tüketimin eş zamanlı olması hizmetlerin başarısında çalışanların önemini artırmaktadır. Çeşitli eğitim programlarıyla bu durumun bilincine varan işgörenler müşterilere daha iyi hizmet sunmak için onları yakından tanıma adına kişisel ilişki kuracaklardır. Bilindiği üzere müşteri memnuniyetini sağlayabilmek için müşterilerin istek ve beklentilerini karşılayan hizmet sunumu gerçekleştirilmelidir. Bunu sağlamak 
için de müşterilerle kişisel ilişki kurulması gerekmektedir. Müşterilere isimleriyle hitap etmek, çayı kaç şekerli içtiğini bilmek gibi kişisel ilişki kurma yoluyla elde edilen bilgilerle müşterilere daha başarılı hizmet sunumu gerçekleştirilebilir. Araştırmada içsel pazarlamanın olumlu sosyal davranışlara önemli derecede katkı sağladığı görülmektedir. Özellikle içsel pazarlamanın gelişim ve ödül boyutları olumlu sosyal davranışların rol tanımlı olumlu sosyal davranışlara, rol ötesi olumlu sosyal davranışlara ve işbirliğine büyük oranda katkı sağladığı saptanmıştır. Bu durumda eğitim ve seminer gibi çeşitli faaliyetlerle bilgi ve becerilerini geliştirme fırsatı bulan işgörenlerin iş tanımında yer alan görevleri en iyi şekilde yerine getireceği, kendilerinden beklenen hizmet davranışlarının ötesinde davranışlar sergileyeceği, iş yükü fazla olan çalışma arkadaşlarına yardım edeceği söylenebilir. Ayrıca otel işletmelerindeki prim, terfi, takdir gibi ödül sistemlerinin işgörenlerin motivasyonunu artırarak daha iyi hizmet sunmaya teşvik ettiği söylenebilir. Otel işletmelerinde işbirliği açısından takım çalışması önemlidir. Bu nedenle işletme yöneticileri işgörenler arasındaki takım çalışmasını geliştirmeleri için personel eğitimine önem vermeleri gerektiği söylenebilir.

Araştırma sonuçları, otel işletmelerinin içsel pazarlamayı uygularken özellikle gelişim ve ödül boyutlarına daha fazla önem vermesi gerektiğini işaret etmektedir. Bu şekilde bu boyutlarla ilgili içsel pazarlama uygulamalarının işgörenlerin hizmet verme yatkınlığına ve olumlu sosyal davranışlarına daha fazla katkı yapması sağlanabilir. Hizmet kalitesini arttırıp müşteri memnuniyeti sağlamak isteyen otel işletmeleri çalışanlarını önemsemelidirler. Bu kapsamda işletmelerinde içsel pazarlama uygulamalarına yer verip çalışanların kendilerini geliştirmelerine fırsat vermeleri ve iyi performans gösterenleri ödüllendirmeleri, çalışanların daha istekli çalışmalarını sağlayabilir. Bu araştırmada otel işletmelerinde içsel pazarlama uygulamaları, hizmet verme yatkınlığı ve olumlu sosyal davranışlar ile ilişkilendirilmiştir. Daha sonraki çalışmalarda otel işletmelerinde içsel pazarlama uygulamaları örgütsel bağlılık, iş tatmini, hizmet kalitesi, müşteri memnuniyeti gibi değişkenlerle ilişkilendirilerek incelenebilir. Ayrıca, elde edilen araştırma sonuçları, araştırmanın sınırlı bir bölgede yapıldığı, örneklemin sınırlı sayıda ve nitelikte işletmeyi kapsadığı dikkate alınarak değerlendirilmelidir. Bu nedenle, bu çalışmada önerilen model, tesadüfi olarak seçilen daha büyük bir örnek hacmi ile Türkiye genelinde test edilebilir.

\section{Kaynakça}

Altunışık, R., Coşkun, R., Bayraktaroğlu, S. ve Yıldırım, E. (2007), Sosyal Bilimlerde Araştırma Yöntemleri SPSS Uygulamalı, Sakarya:Sakarya Yayıncılık.

Arnett, B., Laverie, A. ve McLane, C. (2002), "Using Job Satisfaction and Pride as Internal Marketing Tools". Cornell Hotel and Restaurant Administration Quarterly, 34, ss. 87-96.

Başaran, Ü., Büyükyılmaz, O. ve Çevik, E.İ. (2011), "İçsel Pazarlamanın Algılanan Hizmet Kalitesi Üzerindeki Etkisinde İş Tatmininin Aracılık Rolü". İşletme Fakültesi Dergisi 12(2), ss. 201-225.

Bell, S.J., Mengüç, B. ve Stefani, S.L. (2004), "When Customer Disappoint: A Model of Relational Internal Marketing and Customer Complaints". Journal of the Academy of Marketing Science 32(2), ss. 112-126.

Bellou, V. ve Andronikidis, A.(2008), "The Impact of Internal Service Quality on Customer Service Behaviour: Evidence From The Banking Sector". International Journal of Quality \& Reliability Management 25(9), ss. 943-954.

Berry, L. (1981), "The Employee as Customer". Journal of Retail Banking, 3(1), s.s. 271-278.

Bettencourt, L.A. ve Brown, S.W. (1997), "Contact Employees: Relationships Among Workplace Fairness, Job Satisfaction and Prosocial Service Behaviors". Journal of Retailing, 73(1), ss. 39-61. 
Carlo, G., Hausmann, A., Christiansen, S. ve Randall, B.A. (2003), "Sociocognitive and Behavioral Correlates of a Measure of Prosocial Tendencies for Adolescents". Journal of Early Adolescence, 23(1), s.s. 107-134.

Carraher, S.M., Mendoza, J.L., Buckley, M.R., Schoenfeldt, L.F. ve Carraher, C.E. (1998), "Validation of an Instrument to Measure Service-Orientation". Journal of Quality Management, 3(2), s.s. 21l-224.

Churchill, G.A.(1996), Basic marketing research, The Dryden Pres, Fort Wort.

Donavan, D.T. (1999), Antecedents and Consequences of the Contact Empoloyee's Service Orientation: From Personality Traits to Service Behaviors, Oklahoma State University.

Donavan, D.T., Brown, T.J. ve Mowen, J.C. (2004), "Internal Benefits of Serviceworker Customer Orientation: Job Satisfaction, Commitment, and Organizational Citizenship Behaviors". Journal of Marketing 68, ss. 128-146.

Eren, D.(2007), Örgütsel Hizmet Odaklıı̆ı̆ İşletme Performansı Üzerindeki Etkisi: Konaklama İşletmelerinde Bir Uygulama, Yayımlanmamış Doktora Tezi, Erciyes Üniversitesi, Sosyal Bilimler Enstitüsü, İşletme Anabilim Dalı, Kayseri.

Foreman, S.K. ve Money, A.H. (1995), "Internal Marketing: Concepts, Measurement and Application". Journal of Marketing Management 11, ss. 755-768.

Hair, J.F., Anderson, R.E., Tahtam, R.L. ve Black, W.C (1998), Multivariate Data Analysis, Prentice-Hall International,New Jersey.

Hoffmann, M.L. (1982), Development of Prosocial Motivation: Empathy and Guilt, Eisenberg (Edt.), The Development of Prosocial Behavior ( pp. 281-313). New York: Academic Press,

Hwang, I.S. ve Chi, D.J. (2005), "Relationships among Internal Marketing, Employee Job Satisfaction and International Hotel Performance: An Empirical Study". International Journal of Management 22(2), ss. 285-293.

İşler, D.B. ve Özdemir, Ş. (2010), "Hastane İşletmelerinde İçsel Pazarlama Yaklaşımının İş Tatmini ve Örgütsel Bağlılık Üzerine Etkisi: Isparta İli Örneği. Hacettepe Sağlık Idaresi Dergisi 13(2), s.s. 115-142.

Judd, C.M., Smith, E.R. ve Kidder, L.H. (1991,) Research Methods in Social Relations. Forth Worth: Hartcourt Brace Jovanovich College Publishers.

Kilchyk, I. (2009), A Study of Person-Job Fit in Front Office Employees in Midwestern Hotels, Master of Science, Purdue University, West Lafayette, Indiana.

Kuşluvan, S. ve Eren, D. (2011), "İşgörenlerin Kişilik Özelliği Olarak Hizmet Verme Yatkınlığı ve Ölçümü: Bir Literatür Taraması". Anatolia: Turizm Araştırmaları Dergisi, 22(2), s.s. 139-153.

Lings, I.N. (2004), "Internal Market Orientation: Construct and Consequences". Journal of Business Research, 57, ss. 405-413.

Malhotra, N.K. (1996), Marketing Research: An Applied Orientation. New Jersey: Prentice-Hall Inc.

Petrillose, M.J. (1995), An Empirical Analysis of Service Orientation and İts İmpact on Employee Job Performance in Upscale Hotels, Kansas State University, USA.

Rafıq, M. ve Ahmed, P.K. (1993), "The Scope of Internal Marketing: Defining the Boundary between Marketing and Human Resource Management". Journal of Marketing Management, 9, ss.219-228.

Rafiq, M. ve Ahmed, P.K. (2000), "Advances in the Internal Marketing Concept: Definition, Synthesis and Extension". Journal of Services Marketing, 14(6), ss. 449-462.

Varey, R.J, ve Lewis, B.R.(1999), "A Broadened Conception of Internal Marketing". European Journal of Marketing 33( 9/10), ss. 926-944.

Yoon, M.H. ve Suh. J. (2003), "Organizational Citizenship Behaviors and Service Quality as External Effectiveness of Contact Employees". Journal Business Research, 56(8), s.s. 597-611. 